\title{
Relating ring width of Mediterranean evergreen species to seasonal and annual variations of precipitation and temperature
}

\author{
W. Nijland ${ }^{1}$, E. Jansma ${ }^{1,2,3}$, E. A. Addink ${ }^{1}$, M. Domínguez Delmás ${ }^{3}$, and S. M. De Jong ${ }^{1}$ \\ ${ }^{1}$ Utrecht University, Faculty of Geosciences, Utrecht, The Netherlands \\ ${ }^{2}$ Cultural Heritage Agency, Amersfoort, The Netherlands \\ ${ }^{3}$ The Netherlands Centre for Dendrochronology RING, Amersfoort, The Netherlands
}

Received: 5 November 2010 - Published in Biogeosciences Discuss.: 13 January 2011

Revised: 4 May 2011 - Accepted: 6 May 2011 - Published: 13 May 2011

\begin{abstract}
Plant growth in Mediterranean landscapes is limited by the typical summer-dry climate. Forests in these areas are only marginally productive and may be quite susceptible to modern climate change. To improve our understanding of forest sensitivity to annual and seasonal climatic variability, we use tree-ring measurements of two Mediterranean evergreen tree species: Quercus ilex L. and Arbutus unedo L. We sampled 34 stems of these species on three different types of substrates in the Peyne study area in southern France. The resulting chronologies were analysed in combination with $38 \mathrm{yr}$ of monthly precipitation and temperature data to reconstruct the response of stem growth to climatic variability. Results indicate a strong positive response to May and June precipitation, as well as a significant positive influence of early-spring temperatures and a negative growth response to summer heat. Comparison of the data with more detailed productivity measurements in two contrasting years confirms these observations and shows a strong productivity limiting effect of low early-summer precipitation. The results show that tree-ring data from Q.ilex and A.unedo can provide valuable information about the response of these tree species to climate variability, improving our ability to predict the effects of climate change in Mediterranean ecosystems.
\end{abstract}

\section{Introduction}

Mediterranean regions are regarded as an outstandingly rich area with respect to history, geography and biodiversity. Mediterranean areas are species-rich and form original biogeographic regions due to a unique combination of climate, relief, soil and long-term human use of the landscape (Naveh

Correspondence to: W. Nijland (geo.uu@wiebenijland.nl) and Kutiel, 1990). The Mediterranean is also a very attractive place for living and recreation. Pressure on the Mediterranean environment and water resources is therefore high and generally increasing (Grenon and Batisse, 1989; UNEP, 2009).

Forest growth in Mediterranean environments is mostly water limited because of the warm, dry summers. This strong limitation results in slow succession rates and climax vegetations characterized by moderate or low above-ground biomass (Di Castri and Mooney, 1973; Rambal, 2001). The predicted climate change for the Mediterranean countries consists of an increase of the extreme character, including longer periods of drought, more concentrated rainfall, and increased mean temperatures (Hertig and Jacobeit, 2008; Gao and Giorgi, 2008; Gibelin and Déqué, 2003). This will promote drought stress and may lead to a decrease in vegetation productivity and possible a loss of species (biodiversity) and ultimately desert-like conditions. Mediterranean ecosystems are very sensitive to climate change, because growth is already strongly limited and forests are only marginally productive. Small changes in water availability and temperature may have considerable impacts on the resilience of the present natural vegetation types. Mediterranean landscapes have a worldwide significance because their ecosystems are widely recognized as biodiversity hotspots, with a species density surpassed only in tropical forests (Gómez-Campo, 1985; Vogiatzakis et al., 2006; Medial and Quezel, 1999). Apart from its ecological value, vegetation cover also protects against soil erosion, provides food for livestock and decreases flooding risks by interception and retention of precipitation. Because vegetation has so many functions and effects on the landscape, any changes in vegetation cover or productivity will have a large impact on the ecology as well as for the human inhabitants.

Published by Copernicus Publications on behalf of the European Geosciences Union. 
To accurately predict the possible effects of climate change on Mediterranean forest ecosystems it is important to understand the relationship between plant growth and the most important climate variables. The main question in this context is: "which climatic variables most strongly affect vegetation productivity?" This study investigates the local relationship between annual vegetation productivity of Mediterranean trees and meteorological variables (i.e. annual and seasonal variations of rainfall and temperature).

Climate-productivity relations have been studied extensively for agricultural crops (e.g. Van Keulen and Wolf, 1986) and to a lesser extent for production forests, but are largely unknown for many natural vegetation types. Good progress is being made using computer-modelling experiments (Reichstein et al., 2003; Hoff et al., 2002; Landsberg and Waring, 1997; Running and Coughlan, 1988) and global or regional studies using satellite observation (Field et al., 1995; Nemani et al., 2003; Reichstein et al., 2007), but besides flux-tower measurements and small-scale laboratory tests, little validation data is available (Pereira et al., 2007; Chiesi et al., 2005; Hanson et al., 2004; Baldocchi and Xu, 2007).

Relating stem growth to seasonal and annual records of rainfall and temperatures using absolutely dated annual treering width may result in new information about the effects of climate change on tree growth in the Mediterranean region. Stem-growth increments as recorded in annual tree rings are an accurate record of past stem growth and more generally of past forest productivity. Productivity and stem growth are influenced by both regional and local processes. Local factors like soil depth, nutrient and mineral availability, slope exposition, and competition between individuals causes stem growth to show significant local variations. This study however focuses on the impact of the overall regional variation of precipitation and temperature on stem growth.

Tree rings are also used as a climate proxy for reconstructing past climates beyond the available instrumental records (dendroclimatology) (Briffa, 2000; Jones et al., 1998; Fritts, 1976). Dendroclimatic reconstructions in general focus on high latitude or high altitude sites where temperature is the main growth-limiting factor and as a result are mainly representative for temperature (Martinelli, 2004; Grudd et al., 2002; Briffa et al., 2004; Büntgen et al., 2005, 2010). Mediterranean climates are characterised by a significantly uneven distribution of rainfall over the year with concentrations of precipitation in autumn and spring, and by a regular occurrence of severe moisture deficits in the summer months (Fig. 1). These climatic characteristics cause tree growth to be mainly limited by water availability. Therefore annual tree growth in this region most likely reflects water availability or drought rather than temperature.

The comparison of Mediterranean tree-ring chronologies of needle-leaf and deciduous species to climate data shows a positive growth response to winter and spring precipitation, and a negative response to summer temperature (Martín-

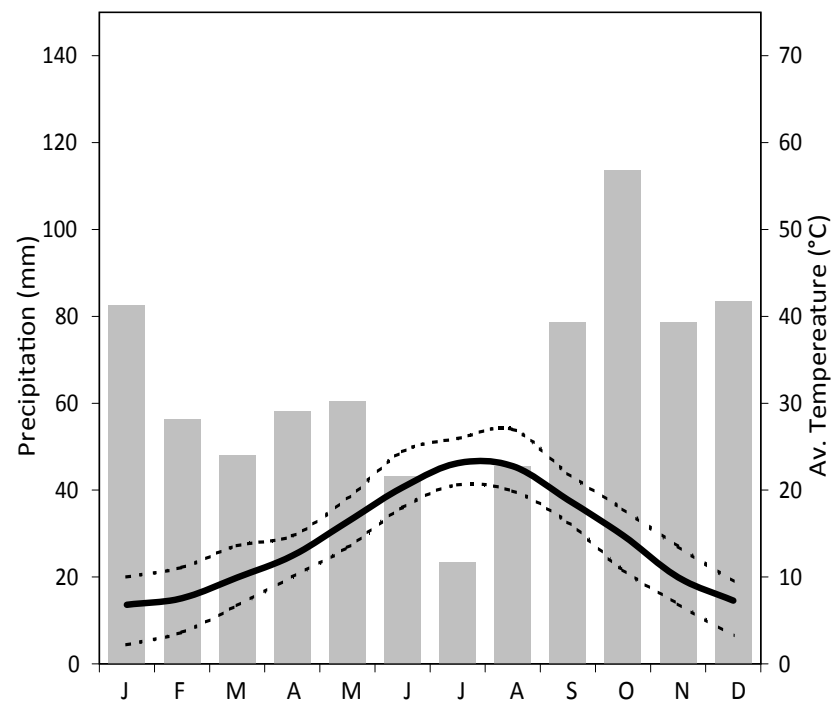

Fig. 1. Yearly average climate diagram of the study area for 19702008. Bars: precipitation, continuous line: average temperature, dashed lines: monthly average minimum and maximum temperature.

Benito et al., 2008; Campelo et al., 2007; Tessier et al., 1994). Longer chronologies of needle-leaf trees have been successfully used to reconstruct precipitation and drought fluctuations in the Mediterranean basin and Canadian prairies for time intervals of $500 \mathrm{yr}$ and longer (Nicault et al., 2008; Touchan et al., 2005; Case and MacDonald, 1995). Evergreen trees do not always show a clear winter stop in their growth because they have leaves all year around. In addition their growth may halt during summer because of water shortage. These phenomena cause a lack of well-defined annual rings in their wood. Mediterranean species are therefore difficult to date accurately, and few dendrochronological studies are available from Mediterranean ecosystems. Cherubini et al. (2003), however, point out that if sufficient care is taken with the selection, sampling and counting, it is possible to use these species for tree-ring analysis. Cherubini et al. (2003) further claim that such analyses would provide valuable insights in tree-growth processes and sensitivity of evergreen Mediterranean species to anticipated climate change.

Recent studies on Holm oak (Quercus ilex) tree-ring chronologies from Portugal and Spain illustrate the possibility of using this evergreen species for dendroclimatologic analyses and show good correspondence between tree growth and precipitation (Campelo et al., 2009) as well as temperature (Patón et al., 2009) in and before the growing season. Holm oak often shows a double growing season around a period of drought-induced rest (Patón et al., 2009; Campelo et al., 2007). Their conclusion are that spring is the most important growing season and that high precipitation in late summer or early autumn triggers the formation of wide double rings. 
As part of a larger study of the effects of climatic change on ecosystem productivity in the Mediterranean we were keen to know which meteorological variables steer biomass production most. The common approach in this case is to apply computer models, which can also be used to evaluate the effects of different climate-change scenarios. However, validation of model performance is limited by data availability from small-scale experiments or indirect data from satellite imagery. In this context tree-ring analysis may provide additional information on past forest productivity and its sensitivity to climate variability. The advantage of ring-width data is that they are available over extended periods of time and are archived in existing forests. Our study area contains different geological substrates which have different water-holding capacities (Nijland et al., 2010) and we would like to know if biomass production on different substrates responds differently to climatic variables. The two dominant tree species in the area are strawberry tree (Arbutus unedo L.) and holm oak (Quercus ilex L.) and we would also like to know if they show the same growth response to climatic variations.

The research questions of this study therefore are:

1. Which meteorological variables have the strongest effect on forest productivity of the evergreen Mediterranean species Q.ilex and A.unedo as expressed in annual stem-growth increments?

2. Is there a difference in the climate sensitivity of A.unedo and Q.ilex co-existing in the same area?

3. Is there a difference in the climate sensitivity of these species growing on different geological substrates?

\section{Methods}

\subsection{Study Area}

The study area is situated in the catchment basin of the Peyne river, a tributary to the Herault in southern France (Fig. 2). The region has a Mediterranean sub-humid climate with dry summers and maximum precipitation in autumn (Fig. 1). The annual precipitation sum is very variable, ranging from 400 to $1200 \mathrm{~mm}$ with a long-term average just below $800 \mathrm{~mm}$. The mean annual temperature is around $14^{\circ} \mathrm{C}$ with monthly average summer temperatures between 20 and $27^{\circ} \mathrm{C}$ and monthly average winter temperatures between 2 and $10^{\circ} \mathrm{C}$. The vegetation on the natural sites of the study area is sclerophyll and consists mostly of evergreen shrubs and trees, heath species, odorous herbs and grasses. Dominant species in the area are Q.ilex (holm oak), A.unedo (strawberry tree), Quercus pubescens Wild. (downy oak) and Erica arborea L. (tree heath). Mixed deciduous-evergreen oak forests with dense undergrowth are considered the climax vegetation in the area (Tomaselli, 1981), but on the marginal soils this vegetation type usually does not develop. Depending on substrate and

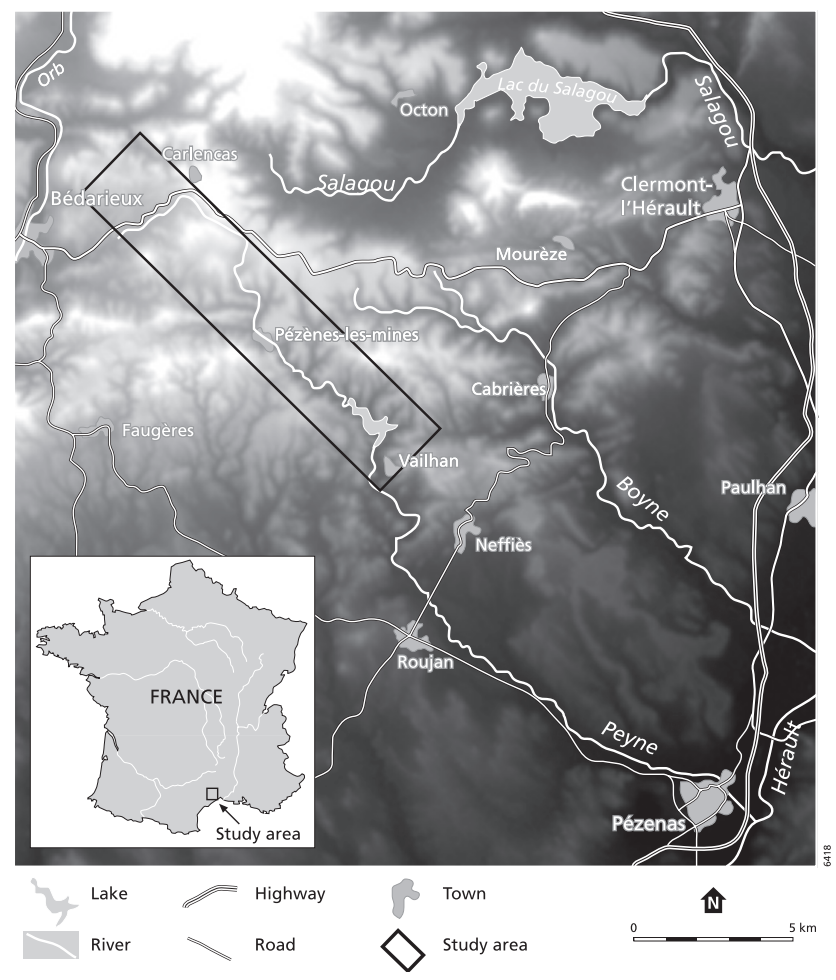

Fig. 2. Location of the study area in Southern France.

history, all types ranging from open scrublands to low dense forests with sparse understory occur (Sluiter and De Jong, 2007; Debussche et al., 1996). The catchment basin is situated at the edge of the "Montagne Noir" and is characterized by a high spatial variation of geological substrates. These substrates vary with respect to soil type, soil depth and moisture storage capacity, which also might influence the vegetation productivity. Trees were sampled on three types of substrate: dolomite, calcareous sandstone, and flysch (Alabouvette, 1982). Soils are shallow and poorly developed and classify as regosols or lithosols according to the FAO soil classification system (Driessen et al., 2001).

\subsection{Trees}

The two dominant tree species of the Peyne area are considered in this study: Q.ilex and A.unedo. Both species are evergreen and tree heights in our study area range between 3 and $12 \mathrm{~m}$.

Quercus ilex L. family: Fagaceae. (FR: chêne vert) is a sclerophyllous oak species abundant in large parts of the Mediterranean basin. The leaves are persistent, leather like and variable in form and size. They are mostly elliptical (dimensions: 2 to $7 \mathrm{~cm}$ long and 1 to $3 \mathrm{~cm}$ wide) and sometimes have a spiny edge. Flowering is in spring and the acorns ripen in one year (Blamey and Gray-Wilson, 2004). Q.ilex wood is semi-ring-porous with larger vessels formed in spring and generally smaller vessels spread throughout 
the summer wood. The wood has pronounced radial rays (Schweingruber, 1993).

Arbutus unedo L. family: Ericaceae. (FR: arbousier) is a tree-like shrub of the heather family growing up to $10 \mathrm{~m}$ tall. Leafs are dark green and glossy (dimensions: 5 to $10 \mathrm{~cm}$ long and 2 to $3 \mathrm{~cm}$ wide), with a serrated margin. It flowers in autumn with panicles of bell shaped flowers and has a red rough-surfaced berry (diameter: 1 to $2 \mathrm{~cm}$ ) which ripens during the next summer season (Blamey and Gray-Wilson, 2004). The wood of A.unedo is diffuse-porous with most of the vessels formed in spring with often a denser ring of vessels formed at the onset of the growing season.

Most forests in the Peyne area have been managed in the past as coppices for charcoal production (Mather et al., 1999). When the forests were cleared, the root systems remained intact and the forests recovered quickly through resprouting. This is still recognizable in the current forest morphology, many smaller stems being grouped in stools that share a common root system.

\subsection{Data collection}

To obtain ring-width samples, live tree stems were felled and disks were cut from a straight section of the stems at 50 to $100 \mathrm{~cm}$ from ground level. A first test series of disks was collected in September 2007. During this field campaign we also sampled a number of trees using an increment corer. After preparation of the cores it proved impossible to obtain accurate ring counts based on the narrow cores, for three reasons: (1) both species show only weak seasonality, (2) some annual rings are locally missing, and (3) Q.ilex has pronounced rays which interfere with the rings in sections of little annual growth. For these reasons the core samples were omitted from this study and we focussed on the disks. To increase the number of samples we collected a second series of tree disks in June 2009. In total 34 trees where sampled: 19 Q.ilex and 15 A.unedo. All disks were prepared by first sanding them and then polishing them using silicon carbide abrasive. The prepared disks were digitized on a $2400 \mathrm{dpi}$ flatbed scanner and their images were enhanced for increased contrast and sharpness. The rings were counted along two radial sections following the growth direction of wood. The location of the sections was chosen visually in order to avoid sections with strongly compressed rings and reaction wood as much as possible. The rings were measured manually on screen using CooRecorder (Larsson, 2010) and while doing this we verified our observations by looking at the original wood through a stereomicroscope with magnification of $8 x$ to $32 \times$. The on-screen method allowed for accuracy assessment and correction of false and missing rings. For the dating and comparison of tree-ring curves using the program Past4 (Knibbe, 2010). The steps were:

Cross dating the series: (1) Detrending measurement series using logarithms of first differences between adjacent ring widths (xi-xi-1) (Holstein, 1980). (2) Calculating Stu- dent's t-values based on Pearson cross-correlation coefficients between the series (Wonnacott and Wonnacott, 1990; Jansma, 1995). (3) Calculating percentage of parallel variation between the series "Gleichlaufichkeit" (Holstein, 1980).

Verification of results: to verify results and check for measuring mistakes and missing rings we used: (1) COFECHA (Holmes, 1983). (2) Visual verification of anomalous growth, possible missing rings and measuring mistakes by on-screen comparison of undetrended (raw) ring-width curves and microscope observations of the colour and cell structure of the wood.

\subsection{Meteorological data}

Monthly rainfall sums and temperature averages, were obtained from the Meteo France observation station in Gignac $\left(43^{\circ} 39^{\prime} 48^{\prime \prime} \mathrm{N} ; 3^{\circ} 33^{\prime} 48^{\prime \prime} \mathrm{E}\right.$, altitude $\left.58 \mathrm{~m}\right)$, which is about $30 \mathrm{~km}$ from the study site and at a similar distance to the Mediterranean Sea. Data is available from 1970 to 2008 (38 yr). Figure 1 shows the monthly averages over the whole period of observation.

\subsection{Detailed carbon flux data}

Gross-Primary-Productivity (GPP) data derived from flux tower measurements from 2000 to 2008 are used in this study as source of temporally detailed reference data to complment the yearly tree ring widths. The CarboEuropeIP site Puechabon (FRpue) is situated at approximately $35 \mathrm{~km}$ from our research area in an evergreen forest dominated by Q.ilex. A detailed analysis of the flux data is published in Allard et al. (2008) and the data is publicly available (Rambal et al., 2010). From the available variables in the flux data, we use the GPP because it is most closely related to photosynthesis and includes all of the different influces like water availibility, incoming solar radiation, and temperature.

\subsection{Chronologies}

The common signal of the individual measurement series was checked using Cofecha (Holmes, 1983; Grissino-Mayer, 2002). The series were averaged into three chronology types: (a) one single chronology representing all series regardless of tree species and substrate; (b) two species-specific chronologies; and (c) three substrate-related chronologies. For each of the chronologies we only used samples with a high common signal as expressed by the series intercorrelation calculated with Cofecha. Samples with a low common signal caused by reaction wood, local processes or suspected misdating were excluded from the chronologies in order to strengthen the common regional signal in the data. Before combining the measurements in the chronologies, the individual ring width series were normalised and detrended using a smoothingspline function with $50 \%$ frequency response for a period of $32 \mathrm{yr}$ (Bunn, 2008). The normalised series are expressed 
as ring width index (rwi), which is the actual ring width divided by the expected (trend) ring width. The average rwi equals 1 by definition. The chronologies were compared to monthly precipitation sums and average monthly temperatures, using cross-correlation coefficients (Pearson's R). In addition we used Precon (Fritts, 1991) to create bootstrapped response functions. Bootstrapped response functions are a statistically more robust way to compare dendrochronological and meteorological time series and in addition they allow for significance testing (Guiot, 1991).

\section{Results}

Cross-sections were taken from 34 trees in total (19 Q.ilex and 15 A.unedo). Stem diameters were between 8 and $16 \mathrm{~cm}$, which is representative for the tree population in the area.

Annual ring boundaries were difficult to discern in the samples of both species (clear colour signature was absent) with average ring widths below $1 \mathrm{~mm}$, and false rings were often present due to summer dormancy. However, we managed to obtain reliable ring-width measurements and dates for most tree sections, by closely examining the cell structure and colour of the wood.

Q.ilex in a productive growth phase shows wide rings, with the vessel and cell sizes steadily decreasing within the year (Fig. 3a). In less-productive years its rings are narrow and contain few vessels that decrease in size in a more irregular manner. The annual boundaries of narrow rings are characterized by a jump in vessel size that occurs over a wider section of the wood and usually coincides with a transition from a darker to a lighter wood colour (Fig. 3b).

A.unedo has fine rays in the wood and is diffuse porous, but pore density is mostly highest in the earliest-formed part of the ring (Fig. 3c). False rings frequently occurred within the annual rings and are most probably caused by different growing phases and dormancy within the growing season. These "rings" can be differentiated from true annual rings because they have vague boundaries rather than the sharp delineation characteristic for winter dormancy (Fig. 3d).

The trees in the study area mostly grow from stools and therefore have skewed or crooked growth forms. As a result the samples contain abundant reaction wood, which to some extent is also reflected by the ring measurements. The resprouting can also be recognised in the wood section, as anomalously large first rings (Fig. 4). The root mass is large compared to the shoot and leaf biomass in this first growth phase, and competition for light and water is greatly reduced (Floret et al., 1992; Khatouri, 1992). In recent clearcut, the canopy is observed to close in around five years after logging, this is visible in the samples as a decrease and stabilisation of ring widths.

The longest ring record is $78 \mathrm{yr}$ long and the average age for all sampled trees is $55 \mathrm{yr}$. For the analysis we restricted the time series to the maximum length of available
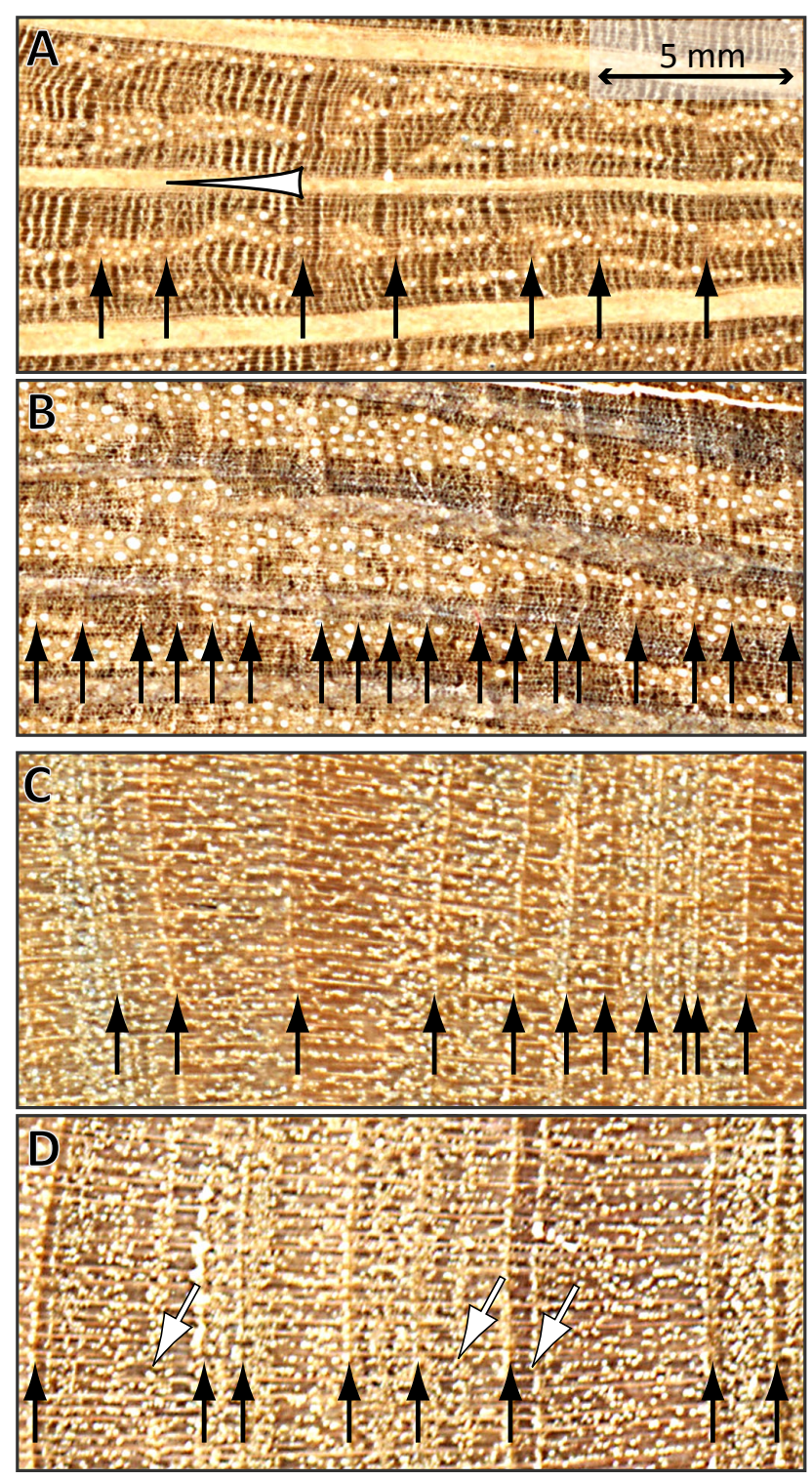

Fig. 3. Example wood sections of (A, B): Q.ilex and (C, D): A.unedo with true (black arrows) and false (white arrows) rings marked. The white marking in (A) indicates the decreasing vessel size within one year. All sections have the same scale.

meteorological data, i.e. 1970 to 2008 , which gives a total of $38 \mathrm{yr}$. By analysing the data for $38 \mathrm{yr}$ while average tree age dates back to $55 \mathrm{yr}$ we excluded the anomalously large rings formed in the first growth years as a result of re-sprouting. For further analysis, ring width chronologies were created from the total pool of ring samples (34 trees $\cdot 2$ samples), and for subsets based on the two tree species and the three different substrates. The species specific chronologies each include all substrates, and the substrate specific chronologies equally represent both species growing on that substrate. Table 1 lists the different chronologies and their 


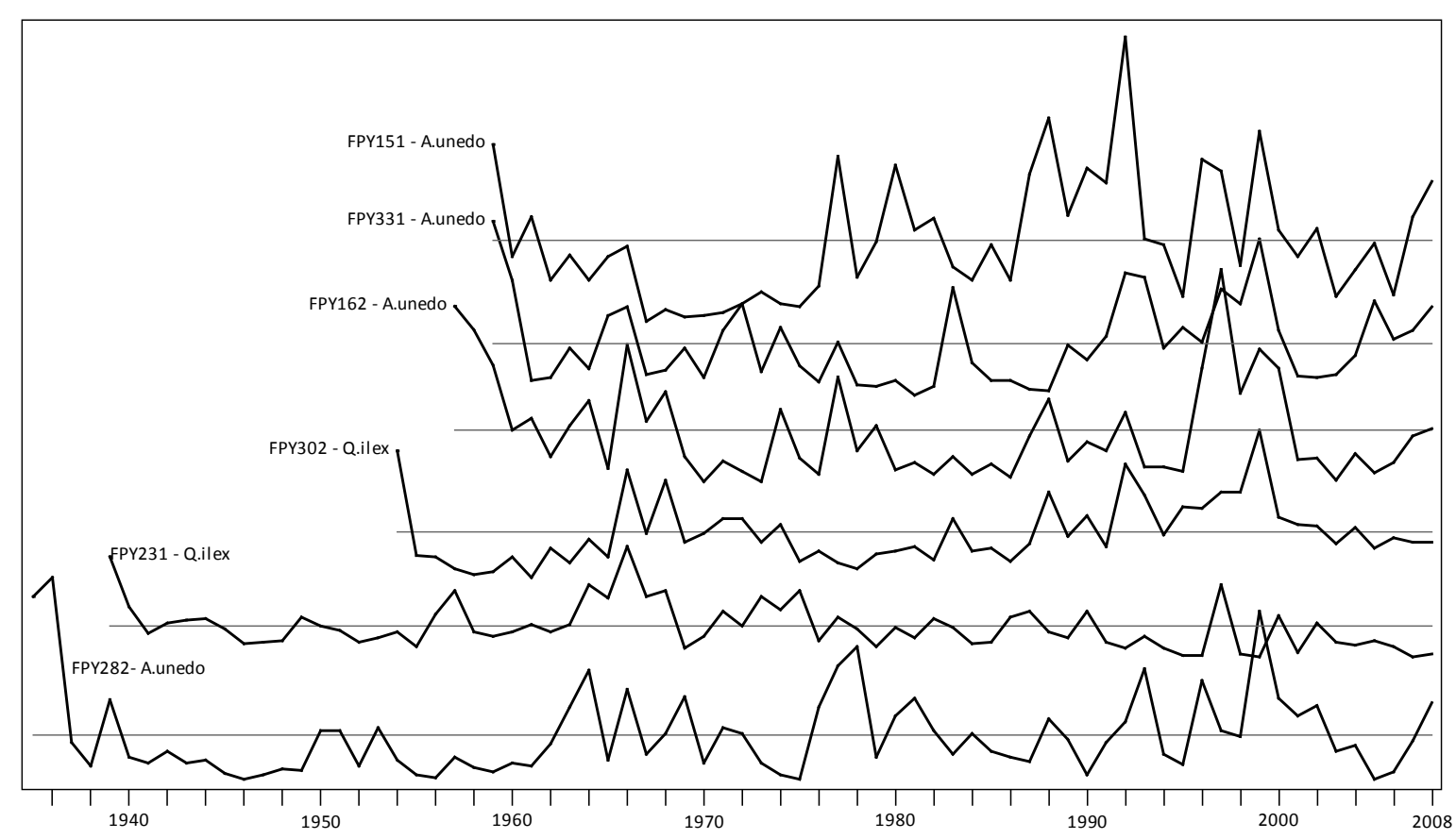

Fig. 4. Example ring-width series with characteristically large first rings reflecting coppice and resprouting growth of the forest.

descriptive statistics. The correlation and sensitivity of the A.unedo chronology are higher than those of Q.ilex, indicating a stronger common forcing on A.unedo. The substrate specific chronologies show a less clear signal with the highest correlation for dolomite and the highest sensitivity for flysch. The number of samples included in the substrate chronologies is limited, but correlations and sensitivity of the series are adequate (above the critical level of 0.32 for $p=0.05$ and $n=38$ ) for further analysis (Table 1).

The normalised ring-width chronologies show very similar patterns throughout the analyzed range, indicating a strong common forcing and accurate relative dating (Fig. 5). Positive pointer years are visible in 1977, 1992, and 1997 and negative pointer years are 1995, 2003 and 2006 (Schweingruber et al., 1990).

\section{Climate response}

Next we analyzed the relationship between ring width and weather conditions. The correlation coefficients and response functions between the annual ring widths and monthly average temperatures and precipitation sums over the period from 1970 to 2008 ( $38 \mathrm{yr}$ ) show a consistent and significant climatic forcing on tree growth (Fig. 6).

The temperature graph shows two main features: a positive temperature/growth relationship in January to April, and a negative one in June and July (Fig. 6a). This means that tree growth benefits from high temperatures at the beginning of the vegetation period and that growth is reduced if summer temperatures are high. The precipitation graph shows a strong positive tree-growth response in May and June, in- dicating a high dependence of the trees on rainfall in these months (Fig. 6b). May and June are the most productive months of the growing season in the area and the clear correlation with precipitation in these months shows that productivity is strongly drought limited. A second feature in the precipitation graph is a small negative growth response in September and October. The negative response is likely to be caused by the correlation between warm summers and high precipitation in these months and shows that the trees in this area do not benefit from the large amounts of precipitation falling in September and October. The growth potential in autumn is low because of the declining temperatures and day length at the end of the vegetation period.

The last bar in each graph shows the relationship between ring width and yearly averaged temperature and precipitation. The correlation with the yearly variables is low and insignificant, showing that analysis of yearly averages does not reveal the actual sensitivity of the trees to climate variability. Both graphs also show little correlation with conditions in the preceding year (August to December), indicating that there is no memory effect in this ecosystem.

Comparison of the climate response functions of Q.ilex and A.unedo (Fig. 7) shows a slight temporal difference between their growth responses, with A.unedo having it strongest response a bit earlier in the season than Q.ilex. Apart from this their response is very similar, which is to be expected because they belong to the same plant-functional type of evergreen broadleaf trees/shrubs. Q.ilex and A.unedo can also be found in mixed stands throughout our study area and other parts of the Mediterranean basin. 
Table 1. Base statistics of the ring-width chronologies.

\begin{tabular}{|c|c|c|c|c|c|c|}
\hline & Total & Q.ilex & A.unedo & dolomite & $\begin{array}{c}\text { calc. } \\
\text { sandstone }\end{array}$ & flysch \\
\hline No. trees sampled & 34 & 19 & 15 & 8 & 9 & 17 \\
\hline Min. age [years] & 34 & 44 & 34 & 34 & 51 & 44 \\
\hline Max. age [years] & 78 & 76 & 78 & 76 & 60 & 78 \\
\hline No. trees used & 23 & 12 & 11 & 8 & 7 & 12 \\
\hline No. radii & 41 & 19 & 22 & 13 & 12 & 19 \\
\hline Average ring width $[\mathrm{mm}]$ & 1.02 & 0.94 & 1.06 & 1.22 & 0.81 & 0.91 \\
\hline Min year-av ring width ${ }^{1}[\mathrm{~mm}]$ & 0.60 & 0.57 & 0.53 & 0.70 & 0.43 & 0.58 \\
\hline Max year-av ring width ${ }^{1}[\mathrm{~mm}]$ & 1.64 & 1.74 & 1.93 & 2.02 & 1.58 & 1.50 \\
\hline \multicolumn{7}{|c|}{ Normalized and detrended series } \\
\hline Min ring width index & 0.65 & 0.68 & 0.53 & 0.58 & 0.65 & 0.60 \\
\hline Max ring width index & 1.61 & 1.64 & 1.98 & 1.70 & 1.83 & 1.59 \\
\hline Average Correlation ${ }^{2}$ & 0.42 & 0.35 & 0.51 & 0.50 & 0.33 & 0.39 \\
\hline Sensitivity & 0.46 & 0.36 & 0.55 & 0.38 & 0.45 & 0.49 \\
\hline \multicolumn{7}{|c|}{ Correlations between chronologies } \\
\hline all & & 0.76 & 0.93 & 0.84 & 0.77 & 0.85 \\
\hline Q.ilex & 0.76 & & 0.50 & 0.79 & 0.59 & 0.56 \\
\hline A.unedo & 0.93 & 0.50 & & 0.69 & 0.71 & 0.86 \\
\hline dolomite & 0.84 & 0.79 & 0.69 & & 0.64 & 0.58 \\
\hline calc. sandstone & 0.77 & 0.59 & 0.71 & 0.64 & & 0.50 \\
\hline flysch & 0.85 & 0.56 & 0.86 & 0.58 & 0.50 & \\
\hline
\end{tabular}

${ }^{1}$ Minimum/maximum of yearly averaged ring widhts in each chronolology.

${ }^{2}$ Average correlation between the radii in each chronology over $38 \mathrm{yr}$.

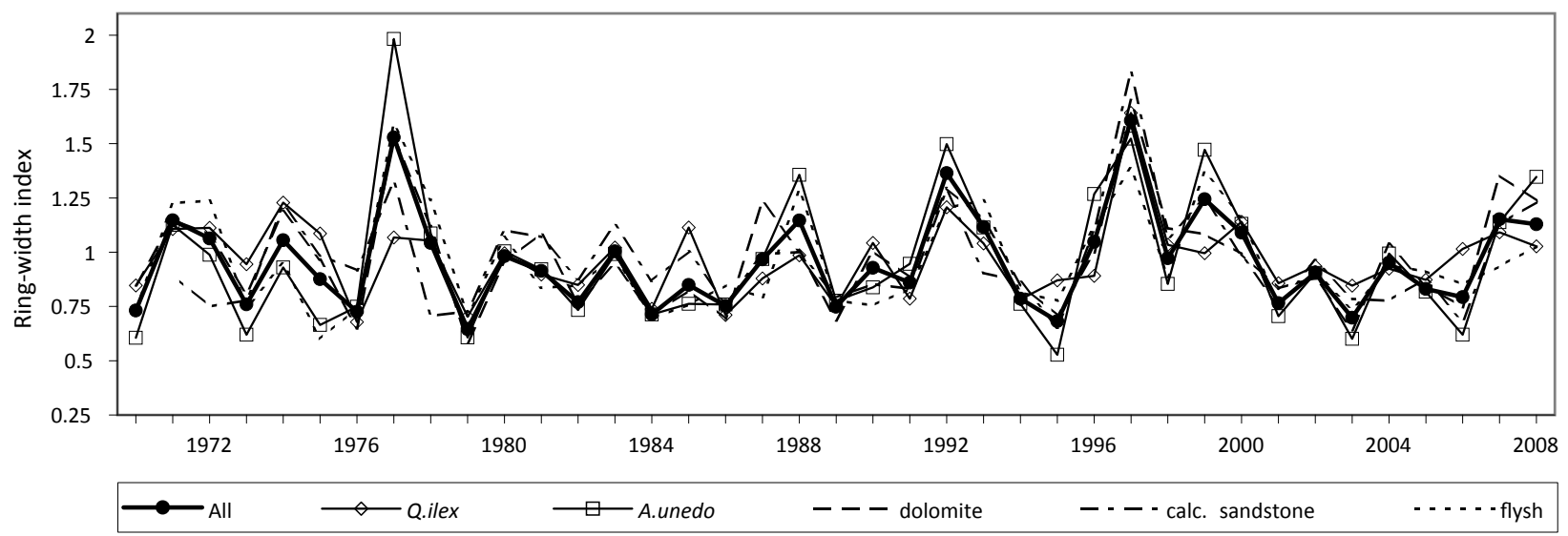

Fig. 5. Normalized and detrended average ring width chronologies.

The differences of the response functions for the three substrate-based chronologies are small (Fig. 8). Conclusive interpretations based on these response functions are necessarily limited due to the low number of samples in each class. The most notable difference occurs between the calcareous sandstone chronology and those of both other substrates, the sandstone chronology showing lower sensitivity to summer temperatures and a high response to August pre- cipitation whereas both other substrate chronologies show no response to precipitation in August.

To examine the processes underlying the yearly wood production in more detail we compared our data to GPP data from flux tower measurements. We specifically looked at 2004 and 2006 as examples of a typical high productive (2004) and low productive (2006) year (Fig. 9). The difference between these two years shows a high correspondence 

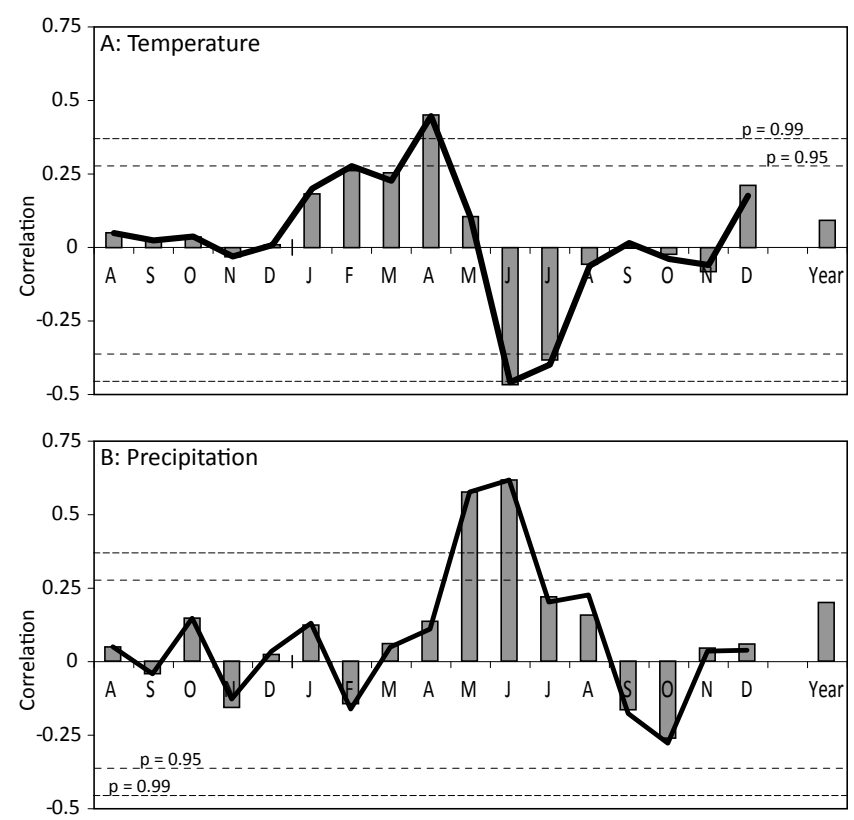

Fig. 6. Correlations (bars) and response functions of monthly average temperatures (A) and precipitation sums (B) with yearly growth indices of the all tree chronology.
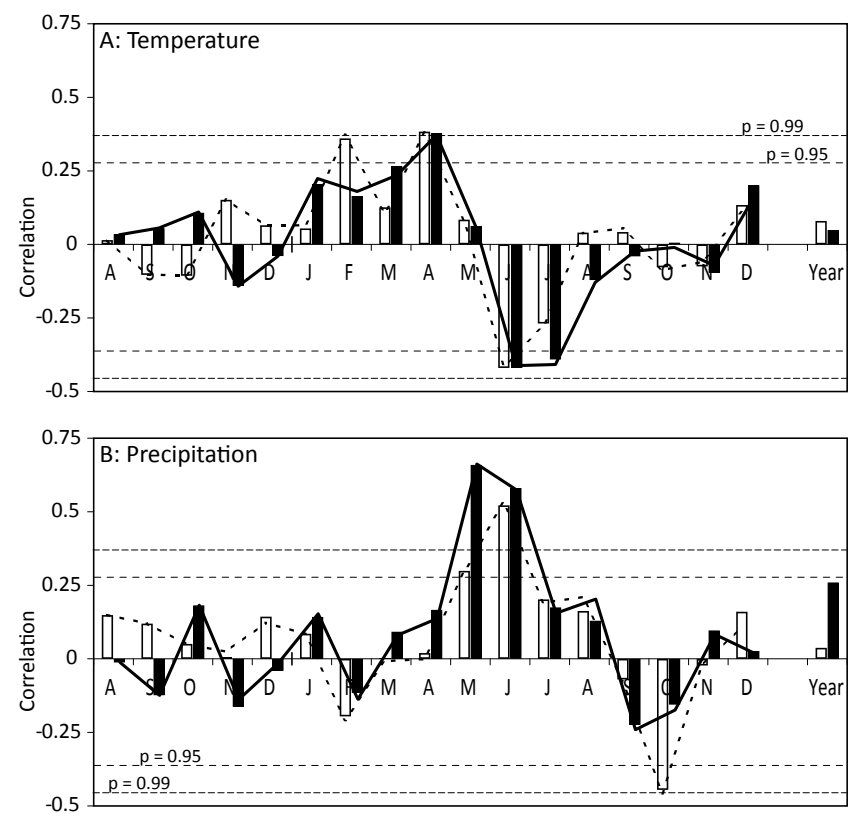

Fig. 7. Correlations (bars) and response functions of monthly average temperatures (A) and precipitation sums (B) with yearly ring widths of the Q.ilex (white) and A.unedo (black) chronology.

with climate response we found in the tree-ring analysis and therefore provides confirmation of the climate/growth responses we inferred for Peyne. Two important differences are visible in the GPP curves of 2004 and 2006. The most striking difference is the large dip in productivity in May to
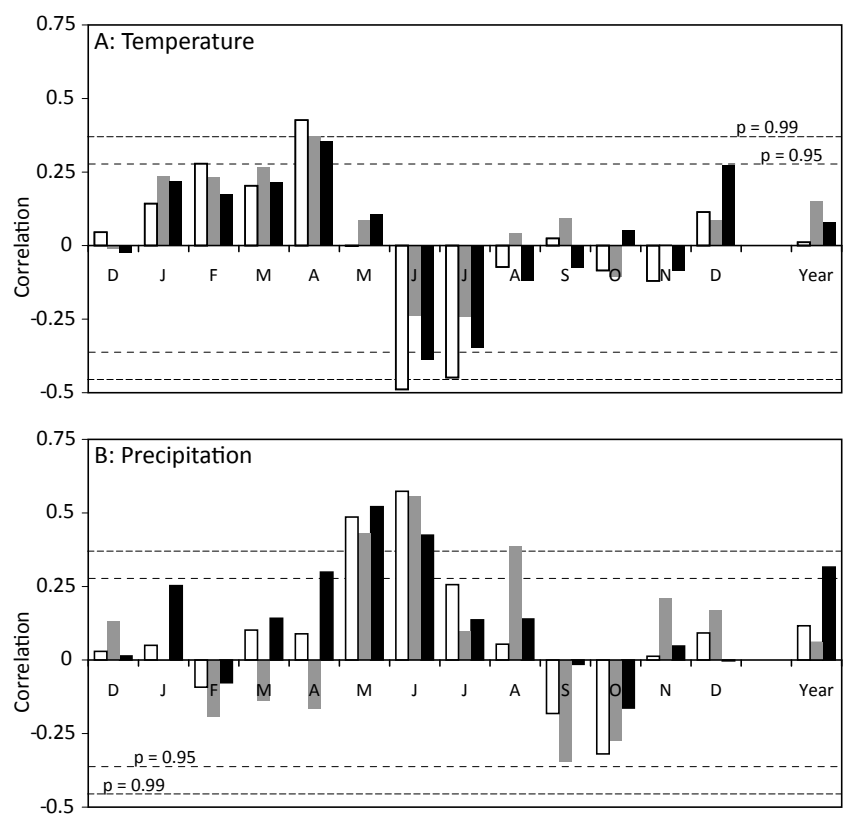

Fig. 8. Correlations of monthly average temperatures (A) and precipitation sums (B) with yearly ring widths of the dolomite (white), calc. sandstone (gray), and flysch (black) chronologies.

August of 2006 where only a narrow dip is present in July and August of 2004. The second difference is a generally higher productivity during the first half of 2004 than during the first half of 2006. The large reduction in 2006 summer productivity is caused by low spring and summer rainfall in combination with high summer temperatures. In 2004 the productivity is also reduced during the warmest part of the summer, but the decline starts much later because of higher spring precipitation. The high productivity in the first half of 2004 is caused by higher early spring temperatures resulting in an early start of the growing season.

\section{Discussion and conclusions}

In this study we present the combined analysis of tree-ring chronologies of two Mediterranean evergreen tree species and $38 \mathrm{yr}$ of monthly temperature and precipitation data from the same area. Despite the difficulties in measuring and dating the annual rings we found consistent ring-width patterns and a strong response of tree growth to climate variability. The analyses prove a significant statistical relation between annual stem increments and monthly meteorological variables and the patterns we found provide valuable insights regarding the mechanisms behind tree growth and the sensitivity of the ecosystem to climate variability. The inferred physiological processes are confirmed by a more detailed temporal look at the ecosystem based on flux-tower measurements.

In our study area, tree growth is purely dependent on the conditions during the growing season, most importantly 

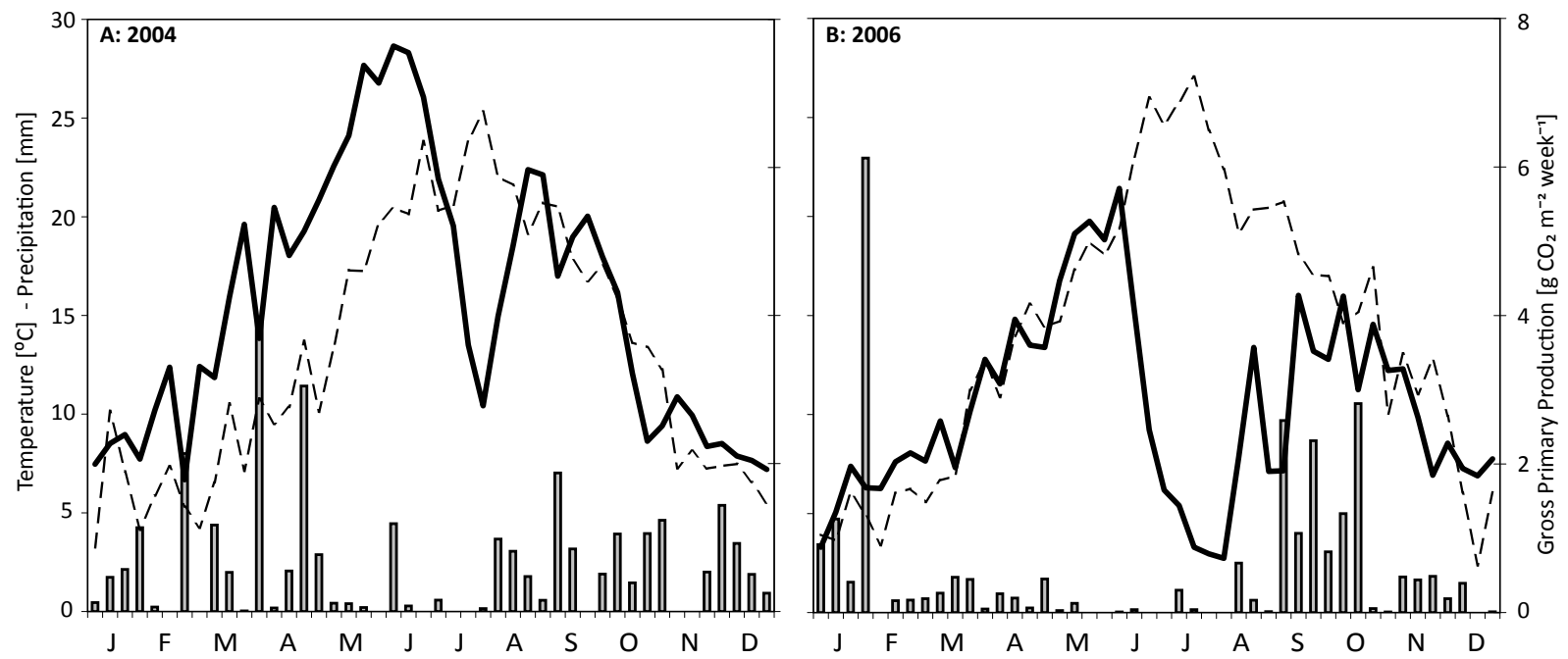

Fig. 9. Weekly ecosystem gross productivity (black line), average temperatures (dotted line), and precipitation (bars), derived from flux measurements at Puechabon CarboEuropeIP test site.

rainfall in May and June. This is in contrast to the results of four independent studies of Q.ilex ring chronologies established in Portugal and Spain. These studies show a stronger sensitivity to winter and early-spring precipitation, most likely because of greater water retention in the soil (Campelo et al., 2009; Patón et al., 2009; Gea-Izquierdo et al., 2009; Nabais et al., 1998). A study on young Q.ilex trees grown from acorns in Montpellier ( $60 \mathrm{~km}$ from our site) shows a response that is similar to the Peyne response, with high climate sensitivity during the current growing season and no response to the conditions during the preceding year (Zhang and Romane, 1991). The response functions for both temperature and precipitation (Fig. 6) show no significant growth response to weather conditions in August, while this month is in the middle of summer season. A possible explanation of this phenomenon is that even in wetter or cooler years both trees species show very little growth in August because growth is still limited by drought and/or heat. The difference we found between the calcareous sandstone and both other substrate chronologies indicates that the vegetation on the former substrate maintains a better growth potential throughout the dry season. Trees on calcareous sandstone show a stronger positive response to August rainfall, which fits with the higher clay content and the deep water retention that is found on this substrate (Nijland et al., 2010)

Modern climate change is expected to intensify the typical characteristics of the Mediterranean climate. Temperatures will increase throughout the year, and rainfall will concentrate more in autumn and winter, leaving a more persistent dry period in summer (Hertig and Jacobeit, 2008; Gao and Girogi, 2008; Gibelin and Déqué, 2003). Our results show that especially an intensification of summer drought may have serious deteriorating effects on tree growth.
The results of a combined analysis of monthly meteorological records and annual tree-ring widths can provide valuable insights in ecosystem functioning and its sensitivity to climate variability and possible climate change. As ring widths from the past are archived in living trees and are readily available for at least the past five decades in most standing forests, they are an important information source for the prediction and modelling of vegetation development. This source at present is underused in Mediterranean climates (Cherubini et al., 2003).

Accurate parameterisation of productivity models is complicated by the scarcity of field data, for example from detailed gas exchange or sap-flow measurements. In absence of other data, ring widths may be used to determine the relative importance of different limiting factors (e.g. water, temperature) on productivity throughout the year. Integration of model results and ring measurements may aim at reproduction of ring width chronologies using forest simulation models, but can also aim at matching the seasonal sensitivity of the models to climatic variability to the response function derived from the analysis of tree ring and meteorological data. By calibrating the models using the seasonal patterns of limiting factors in addition to the total annual productivity or resulting leaf area, the model results are greatly improved especially towards the assessment of climate-change vulnerability. If climate-related stem growth is representative for the overall growth of trees (with other biotic and abiotic factors having a relatively weak impact), and if stem growth during a period of already increased temperature can be compared to growth before increased greenhouse gas concentrations, then the conclusion would be justified that the growth-climate relations we established will be valid in the future. However, the Mediterranean climate is very variable and predicted changes are smaller than the current year to 
year variability contributing to the likeliness of the relation remaining valid in a future changed climate. Although detailed plant-physiological studies remain very important for the understanding of plant growth and ecosystem functioning, tree-ring analysis seems to be a very promising tool for expanding both the temporal scale as well as the geographical coverage of field-validation data.

In this study we focussed on ring width data only, but other studies in Mediterranean areas suggest that more detailed measurements of wood anatomy (Campelo et al., 2010) or including double ring data (Campelo et al., 2007; Zhang and Romane, 1991) may also provide information on the sensitivity of trees to climate.

In conclusion, we found that the evergreens Q.ilex and A.unedo in the Peyne area in southern France are very sensitive to precipitation in the months from April to July and are also sensitive to spring and summer temperatures.The trees hardly benefit from the precipitation surplus in autumn and winter. Both species effectively show a very similar pattern in their climate response. There are little differences between the substrate-related responses, with the examined substrates all being shallow but characterized by different water-retention capacities. Trees growing on the calcareous sandstone are more sensitive to August rainfall than on the other substrates which indicating a larger growth potential during the driest and warmest part of the summer.

Tree-ring analysis of Mediterranean evergreen species is not easy because of frequent false rings and unclear ring boundaries, but accurate measurement and dating is possible if enough care is taken during the preparation and measurement of the samples. Combining ring-width chronologies with meteorological records provides useful information on vegetation functioning and climate sensitivity. Tree stems contain much information that is of great interest to productivity modelling and climate-impact predictions. This information is archived and readily available in every forest.

Acknowledgements. The authors thank Rogier de Jong, Wilco Klutman and "Boomwerk Bilthoven" for their cooperation in felling and sampling the tree stems and Emma Daniëls is kindly acknowledged for her help in the ring width measurements.

Edited by: J. Kesselmeier

\section{References}

Alabouvette, B.: Carte Geologique de la France a 1/50 000: feuille de Lodeve, BRGM Ed., Orleans, France, 1982.

Allard, V., Ourcival, J. M., Rambal, S., Joffre, R., and Rocheteau, A.: Seasonal and annual variation of carbon exchange in an evergreen Mediterranean forest in Southern France, Glob. Change Biol., 14(4), 714-725, 2008.

Baldocchi, D. D. and Xu, L.: What limits evaporation from Mediterranean oak woodlands - the supply of moisture in the soil, physiological control by plants or the demand by the atmosphere?, Adv. Water Resour., 30(10), 2113-2122, 2007.
Blamey, M. and Grey-Wilson, C.: Wild Flowers of the Mediterranean: A Complete Guide to the Islands and Coastal Regions, 2nd edn., A\&C Black Publishers Ltd., London, 2004.

Briffa, K. R.: Annual climate variability in the Holocene: interpreting the message of ancient trees, Quaternary Sci. Rev., 19(1), 87-105, 2000.

Briffa, K. R., Osborn, T. J., and Schweingruber, F. H.: Large-scale temperature inferences from tree rings: a review, Global Planet. Change, 40(1), 11-26, 2004.

Bunn, A. G.: A dendrochronology program library in R (dplR), Dendrochronologia, 26, 115-124, 2008.

Büntgen, U., Esper, J., Frank, D. C., Nicolussi, K., and Schmidhalter, M.: A 1052-year tree-ring proxy for Alpine summer temperatures, Clim. Dynam., 25(2), 141-153, 2005.

Büntgen, U., Frank, D., Trouet, V., and Esper, J.: Diverse climate sensitivity of Mediterranean tree-ring width and density, TreesStruct. Funct., 24(2), 261-273, 2010.

Campelo, F., Gutiérrez, E., Ribas, M., Nabais, C., and Freitas, H.: Relationships between climate and double rings in Quercus ilex from Northeast Spain, Can. J. Forest Res., 37(10), 1915-1923, 2007.

Campelo, F., Nabais, C., Garcia-Gonzalez, I., Cherubini, P., Gutiérrez, E., and Freitas, H.: Dendrochronology of Quercus ilex L. and its potential use for climate reconstruction in the Mediterranean region, Can. J. Forest Res., 39(12), 2486-2493, 2009.

Campelo, F., Nabais, C., Gutiérrez, E., Freitas, H., and GarcíaGonzález, I.: Vessel features of Quercus ilex L. growing under Mediterranean climate have a better climatic signal than tree-ring width, Trees-Struct. Funct., 24(3), 463-470, 2010.

Case, R. A. and MacDonald, G. M.: A dendroclimatic reconstruction of annual precipitation on the Western Canadian Prairies since AD 1505 from Pinus flexilis James, Quaternary Res., 44(2), 267-275, 1995.

Cherubini, P., Gartner, B. L., Tognetti, R., Braeker, U. O., Schoch, W., and Innes, J. L.: Identification, measurement and interpretation of tree rings in woody species from Mediterranean climates, Biol. Rev., 78(1), 119-148, 2003.

Chiesi, M., Maselli, F., Bindi, M., Fibbi, L., Cherubini, P., Arlotta, E., Tirone, G., Matteucci, G., and Seufert, G.: Modelling carbon budget of Mediterranean forests using ground and remote sensing measurements, Agr. Forest Meteorol., 135(1), 22-34, 2005.

Debussche, M., Escarre, J., Lepart, J., Houssard, C., and Lavorel, S.: Changes in Mediterranean plant succession: old-fields revisited, J. Veg. Sci., 7(4), 519-526, 1996.

Di Castri, F. and Mooney, H. A.: Mediterranean type ecosystems: origin and structure, Ecological studies 7, Springer, Berlin, 1973.

Driessen, P., Deckers, J., Spaargaren, O., and Nachtergaele, F.: Lecture notes on the major soils of the world, World Soil Resources Reports 64, FAO, Rome, 334 pp., 2001.

Field, C. B., Randerson, J. T., and Malmström, C. M.: Global net primary production: Combining ecology and remote sensing, Remote Sens. Environ., 51, 74-88, 1995.

Floret, C., Galan, M. J., Floch, E., and Romane, F.: Dynamics of holm oak (Quercus ilex L.) coppices after clearcutting in southern France, Plant Ecol., 99-100, 97-105, 1992.

Fritts, H. C.: Tree Rings and Climate, Academic Press, London, 1976.

Fritts, H. C.: Reconstructing Large-Scale Climatic Patterns from Tree-Ring Data, Tree-Ring Bulletin, 51, 39-41, 1991. 
Gao, X. and Giorgi, F.: Increased aridity in the Mediterranean region under greenhouse gas forcing estimated from high resolution simulations with a regional climate model, Global Planet. Change, 62(3), 195-209, doi:10.1016/j.gloplacha.2008.02.002, 2008 .

Gea-Izquierdo, G., Martín-Benito, D., Cherubini, P., and Isabel, C.: Climate-growth variability in Quercus ilex L. West Iberian open woodlands of different stand density, Ann. For. Sci., 66(8), 802, doi:10.1051/forest/2009080, 2009.

Gibelin, A. L. and Déqué, M.: Anthropogenic climate change over the Mediterranean region simulated by a global variable resolution model, Clim. Dynam., 20(4), 327-339, 2003.

Gómez-Campo, C.: Plant conservation in the Mediterranean area, W. Junk, Doredrecht 1985.

Grenon, M. and Batisse, M.: Le Plan Bleu: Avenirs du Bassin Méditerranéen, Economica, Paris, 1989.

Grissino-Mayer, H. D.: Research report evaluating crossdating accuracy: a manual and tutorial for the computer program COFECHA, Tree-Ring Res., 57(2), 205-221, 2002.

Grudd, H., Briffa, K. R., Karlen, W., Bartholin, T. S., Jones, P. D., and Kromer, B.: A 7400-year tree-ring chronology in Northern Swedish Lapland: natural climatic variability expressed on annual to millennial timescales, Holocene, 12(6), 657-665, 2002.

Guiot, J.: The bootstrapped response function, Tree-Ring Bulletin, 51, 39-41, 1991.

Hanson, P. J., Amthor, J. S., Wullschleger, S. D., Wilson, K. B., Grant, R. F., Hartley, A., Hui, D., Hunt, E. R., Johnson, D. W., Komball, J. S., King, A. W., Luo, Y., McNulty, S. G., Sun, G., Thornton, P. E., Wang, S., Williams, M., Baldocchi, D. D., and Cushman, R. M.: Oak forest carbon and water simulations: model intercomparisons and evaluations against independent data, Ecol. Monogr., 74(3), 443-489, 2004.

Hertig, E. and Jacobeit, J.: Downscaling future climate change: temperature scenarios for the Mediterranean area, Global Planet. Change, 63(2), 127-131, 2008

Hoff, C., Rambal, S., and Joffre, R.: Simulating carbon and water flows and growth in a Mediterranean evergreen Quercus ilex coppice using the FOREST-BGC model, Forest Ecol. Manag., 164, 121-136, 2002.

Holmes, R. L.: Computer-assisted quality control in tree-ring dating and measurement, Tree Ring Bull., 43(1), 69-78, 1983.

Holstein, E.: Mitteleuropäische Eichenchronologie, Philip von Zabern, Mainz, 1980.

Jansma, E: RemembeRINGs. The development and application of local and regional tree-ring chronologies of Oak for the purposes of archaeological and historical research in the Netherlands, Dissertation Amsterdam University, Nederlandse Archeologische Rapporten 19, 1995.

Jones, P. D., Briffa, K. R., Barnett, T. P., and Tett, S. F. B.: Highresolution palaeoclimatic records for the last millennium: Interpretation, integration and comparison with general circulation model control-run temperatures, Holocene, 8(4), 455-471, 1998.

Khatouri, M.: Growth and yield of young Quercus ilex coppice stands in the Tafferte forest (Morocco), Plant Ecol., 99-100, 7782, 1992.

Knibbe, B.: PAST4. SCIEM scientific engineering and manufacturing, available at: http://www.sciem.com, last acces: 9 February 2010.

Landsberg, J. J. and Waring, R. H.: A generalised model of for- est productivity using simplified concepts of radiation-use efficiency, carbon balance and partitioning, Forest Ecol. Manag., 95(3), 209-228, 1997.

Larsson, L.: CooRecoreder User Manual, Cybis Elektronik and Data $\mathrm{AB}$, available at: www.cybis.se/forfun/dendro/, last acces: 10 February 2010.

Martín-Benito, D., Cherubini, P., del Río, M., and Cañellas, I.: Growth response to climate and drought in Pinus nigra Arn. trees of different crown classes, Trees-Struct. Funct., 22(3), 363-373, 2008.

Martinelli, N.: Climate from dendrochronology: latest developments and results, Global Planet. Change, 40(1), 129-139, 2004.

Mather, A. S., Fairbairn, J., and Needle, C. L.: The course and drivers of the forest transition: the case of France, J. Rural Stud., 15(1), 65-90, doi:10.1016/S0743-0167(98)00023-0, 1999.

Médail, F. and Quezél, P.: Biodiversity Hotspots in the Mediterranean Basin: Setting Global Conservation Priorities, Conserv. Biol., 13(6), 1510-1513, 1999.

Nabais, C., Freitas, H., and Hagemeyer, J.: Tree-rings to climate relationships of Quercus ilex L. in the NE-Portugal, Dendrochronologia, 16(17), 37-44, 1998.

Naveh, Z. and Kutiel, P.: Changes in vegetation of the Mediterranean Basin in response to human habitation, in: The earth in transition, patterns and processes of biotic impoverishment, edited by: Woodwell, G. M., Cambridge University Press, Cambridge, 259-300, 1990.

Nemani, R. R., Keeling, C. D., Hashimoto, H., Jolly, W. M., Piper, S. C., Tucker, C. J., Myneni, R. B., and Running, S. W.: ClimateDriven Increases in Global Terrestrial Net Primary Production from 1982 to 1999, Science, 300, 1560-1563, 2003.

Nicault, A., Alleaume, S., Brewer, S., Carrer, M., Nola, P., and Guiot, J.: Mediterranean drought fluctuation during the last 500 years based on tree-ring data, Clim. Dynam., 31(2), 227-245, 25 2008.

Nijland, W., van der Meijde, M., Addink, E. A., and de Jong, S. M.: Detection of soil moisture and vegetation water abstraction in a Mediterranean natural area using electrical resistivity tomography, Catena, 81, 209-216, 2010.

Patón, D., García-Herrera, R., Cuenca, J., Galavis, M., and Roig, F. A.: Influence of climate on radial growth of holm oaks (Quercus ilex subsp. Ballota desf) from SW Spain, Geochronometria, 34(1), 49-56, 2009.

Pereira, J. S., Mateus, J. A., Aires, L. M., Pita, G., Pio, C., David, J. S., Andrade, V., Banza, J., David, T. S., Paço, T. A., and Rodrigues, A.: Net ecosystem carbon exchange in three contrasting Mediterranean ecosystems - the effect of drought, Biogeosciences, 4, 791-802, doi:10.5194/bg-4-791-2007, 2007.

Rambal, S.: Hierarchy and productivity of Mediterranean-type ecosystems, in: Terrestrial Global Productivity, edited by: Saugier, B. and Mooney, H. A., Academic Press, London, 315344, 2001.

Rambal, S., Ourcival, J. M., and Mission, L.: Level 4 dataset CEIP EC L4 FRPue in CarboeuropeIP Ecosystem Component Database, available at: http://gaia.agraria.unitus.it/database, last acces: 2 August 2010.

Reichstein, M., Tenhunen, J., Roupsard, O., Ourcival, J. M., Rambal, S., Miglietta, F., Peressotti, A., Pecchiari, M., Tirone, G., and Valentini, R.: Inverse modeling of seasonal drought effects on canopy $\mathrm{CO}_{2} / \mathrm{H}_{2} \mathrm{O}$ exchange in three Mediterranean ecosystems, 
J. Geophys. Res., 108(D23), 4726, doi:10.1029/2003JD003430, 2003.

Reichstein, M., Ciais, P., Papale, D., Valentini, R., Running, S., Viovy, N., Cramer, W., Cranier, A., Ogee, J., Allard, V., Aubinet, Marc, Bernhofer, C., Buchmann, N., Carrara, Grunwald, T., Heimann, M., Heinesch, Bernard, Knohl, A., Kutsch, W., Loustau, D., Manca, G., Matteucci, G., Miglietta, F., Ourcival, Jm., Pilegaard, K., Pumpanen, J., Rambal, S., Schaphoff, S., Seufert, G., Soussana, Jf., Sanz, Mj., Vesala, T., and Zhao, M.: Reduction of ecosystem productivity and respiration during the European summer 2003 climate anomaly: a joint flux tower, remote sensing and modelling analysis, Glob. Change Biol., 13, 634-651, 2007.

Running, S. W. and Coughlan, J. C.: A general model of forest ecosystem processes for regional applications. I. Hydrologic balance, canopy gas exchange and primary production processes, Ecol. Model., 42(2), 125-154, 1988.

Sluiter, R. and De Jong, S. M.: Spatial patterns of Mediterranean land abandonment and related land cover transitions, Landscape Ecol., 22(4), 559-576, 2007.

Schweingruber, F. H.: Trees and Wood in Dendrochronology: Morphological, Anatomical, and Tree-Ring Analytical Characteristics of Trees Frequently used in Dendrochronology, SpringerVerlag, Berlin, 1993.

Schweingruber, F. H., Eckstein, D., Serre-Bachet, F., and Bräker, O. U.: Identification, presentation and interpretation of event years and pointer years in dendrochronology, Dendrochronologia, 8, 9-38, 1990.
Tessier, L., Nola, P., and Serre-Bachet, F.: Deciduous Quercus in the Mediterranean region: tree-ring/climate relationships, New Phytol., 126(2), 355-367, 1994.

Tomaselli, R.: Relations with other ecosystems: temperate evergreen forests, Mediterranean coniferous forests, savannahs, steppes and desert shrublands, Ecosys. World, 11. Mediterranean-type shrublands, 123-130, 1981.

Touchan, R., Xoplaki, E., Funkhouser, G., Luterbacher, J., Hughes, M., Erkan, N., Akkemik,Ü., and Stephan, J.: Reconstructions of spring/summer precipitation for the Eastern Mediterranean from tree-ring widths and its connection to large-scale atmospheric circulation, Clim. Dynam., 25(1), 75-98, doi:10.1007/s00382-0050016-5, 2005.

UNEP: Plan Bleu: State of the Environment and Development in the Mediterranean, UNEP/MAP-Plan Bleu, Athens, 2009.

Van Keulen, H. and Wolf, J.: Modelling of Agricultural Production: Weather, Soils and Crops, Pudoc, Wageningen, 1986.

Vogiatzakis, I. N., Mannion, A. M., and Griffiths, G. H.: Mediterranean ecosystems: problems and tools for conservation, Prog. Phys. Geog., 30(2), 175-200, 2006.

Wonnacott, T. H. and Wonnacott, R. J.: Introductory statistics, John Wiley and Sons Ltd, New-York, 1990.

Zhang, S. H. and Romane, F.: Variations de la croissance radiale de Quercus ilex L. en fonction du climat, Ann. Sci. Forest., 48, 225-234, 1991. 